\section{Images of Rule}

Art and Politics in the English Renaissance, 1485-1649

\section{David Howarth}

This is a fascinating and highly readable account of the vital role the visual arts played in Great Britain during the Tudor and early Stuart monarchies.

$\$ 50.00$ cloth, $\$ 19.95$ paper, illustrated

\section{Nerves and Narratives}

A Cultural History of Hysteria in Nineteenth-Century British Prose Peter Melville Logan Foreword by Roy Porter

"This highly original study historicizes the novel in just the way I think it needs to be historicized-as the inaugural event in the history of mass culture." - Nancy Armstrong, coauthor $\$ 40.00$ cloth. $\$ 16.00$ paper of The Imaginary Puritan

\section{Writing and Rebellion} England in 1381 Steven Justice

New in paperback-"Original, courageous, and exemplary.... This will prove to be one of the most significant and energizing works of recent decades."-David Wallace, editor of The Cambridge History of Medieval English Literature Winner, MLA Prize for a First Book, 1994; The New Historicism. \$15.95 paper

\section{The Middling Sort}

Commerce, Gender, and the Family in England, 1680-1780

Margaret R. Hunt

"A very full, nuanced, up-to-date, and lucidly expressed account. ... The discussion is impressively wide-ranging (spanning cultural, economic, intellectual, social, and women's history), and makes valuable contributions to a number of current debates."

-Johann Sommerville, University of Wisconsin-Madison $\$ 48.00$ cloth

\section{The Struggle for the Breeches}

Gender and the Making of the British Working Class

Anna Clark

New in paperback - "I he book is full of fascinating detail and comment, with a cast of characters as large as in a picaresque novel or a Victorian threedecker." - The Women's Review of Books Winner, British Council Prize in the Humaniries of the North American Conference on British Studies; Studies on the History of Socien' and Ciulture, $\$ 18.95$ paper, illustrated

At bookstores or order $1-80(0-822-6657$.

UNIVERSITY OF CALIFORNIA PRESS 


\section{Oxford University Press}

\section{ALE, BEER, AND BREWSTERS IN ENGLAND}

Women's Work in a Changing World, 1300-1600

JUDITH M. BENNET

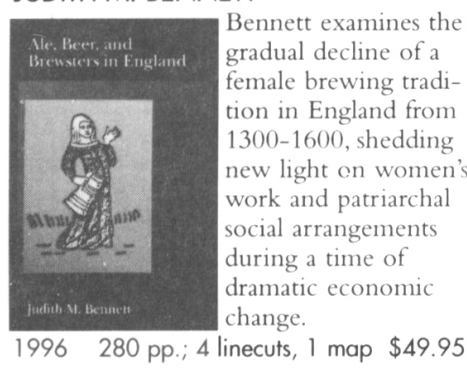

\section{New in paper! CROWNS OF GLORY, TEARS OF BLOOD}

The Demerara Slave Rebellion of 1823

EMILIA VIOTII DA COSTA

"A first-rate account of a little-known episode that had large consequences for Britain and for the world: careful, professional scholarship married to a well-told story."-Kirkus Reviews" A riveting account of the rebellion that gave new urgency to the British Anti-Slavery Movement."

-Quarterly Black Review

1994 (paper 1997) 400 pp.; 2 halftones,

2 maps, 7 linecuts

paper $\$ 17.95$ cloth $\$ 35.00$

\section{HITLER'S ENFORCERS}

The Gestapo and the SS

Security Service in the Nazi

Revolution

\section{GEORGE C. BROWDER}

This first socio-organizational history of the Gestapo, the SD, and the regular detectives of the Third Reich, 1932-1937, explores the roots of their roles in police terror and programs of mass murder. 1996384 pp.; 2 maps $\$ 49.95$
STALIN'S PEASANTS

Resistance and Survival in the Russian Village After

Collectivization

SHEILA FITZPATRICK

"In this pathbreaking study, Sheila

Fitzpatrick portrays collective farm life in the 1930 s from the perspective of the peasantry...Stalin's Peasants is an accessible and fascinating glimpse into the Soviet countryside."-Journal of Social History 1994 (paper 1996) 416 pp. paper $\$ 18.95$

\section{EUROPEAN}

SOCIALISTS RESPOND TO FASCISM IDEOLOGY, ACTIVISM AND CONTINGENCY IN THE 1930S

\section{GERD-RAINER HORN}

Based on documents collected in six European countries, European Socialists Respond to Fascism is a transnational study of largely parallel developments in Austria, Belgium, France, Germany, and Spain in the years 1933-1936

1996224 pp. $\$ 45.00$

\section{FIRST AMONG FRIENDS}

George Fox and the Creation of Quakerism

H. LARRY INGLE

$\begin{aligned} & \text { First Among Friends } \\ & \text { "The last three decades } \\ & \text { have seen a remarkable } \\ & \text { development in } \\ & \text { Quaker historiogra- } \\ & \text { phy...Larry Ingle's } \\ & \text { extraordinary biogra- } \\ & \text { phy of George Fox is } \\ & \text { not only a fitting con- } \\ & \text { tribution to this cor- } \\ & \text { pus, but the essential } \\ & \text { starting place for the }\end{aligned}$
next generation of scholars."-Albion
1994 (paper 1996) 424 pp.; 1 halftone,

Prices are subject to change and apply only in the U.S. To order or for more information, please call 1-800-451-7556. In Canada call 1-800-387-8020. HTTP//WWW.OUP-USA.ORG 


\section{$\approx S t$. Martin's Press}

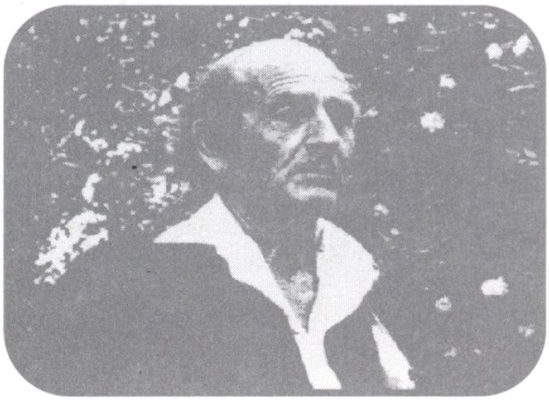

F.R. Leavis

A Life in Criticism

Ian Mackillop

"A comprehensive, meticulously researched and even-handed biography... It is a splendid achievement and a brave one."

-TIMES HIGHER EDUCATION SUPPLEMENT

March 1997 / $493 \mathrm{pp}$. with b\&w illustrations ISBN 0-312-16357-6 $\$ 29.95 \mathrm{cl}$.

\section{Modern British History}

A Guide to Study and Research

Edited by Larry Butler

and Anthony Gorst

This single volume provides both practical research methods and a comprehensive survey of the current state of historical research on twentieth-century British history.

June 1997 / 288 pp

ISBN 1-86064-103-2 \$19.95 pb.

I.B.Tauris

\section{Through the Dark Labyrinth} A Biography of Lawrence Durrell

\section{Gordon Bowker}

Gordon Bowker takes the full measure of Durrell the man and the writer. The result is the first complete biography of one of the major figures of modern literature.
Ireland in the Middle Ages Sean Duffy

IRELAND IN THE MIDDLE AGES, written in a style which will make it accessible to those new to the subject, surveys Irish history in the first half of this millennium. The author incorporates the findings of recent research and offers a reinterpretation of the evidence.

March $1997 / 232 \mathrm{pp}$.

ISBN 0-312-16390-8 \$19.95 pb

British History in Perspective Series

\section{Charles I}

Michael B. Young

Distinguished by its frank discussion of current scholarship, this book is organized around a dramatic narrative of events intended to hold the interest of students and acquaint them with the basic events of Charles' reign

March 1997 / $232 \mathrm{pp}$.

ISBN 0-312-16516-1 \$17.95 pb

British History in Perspective Series

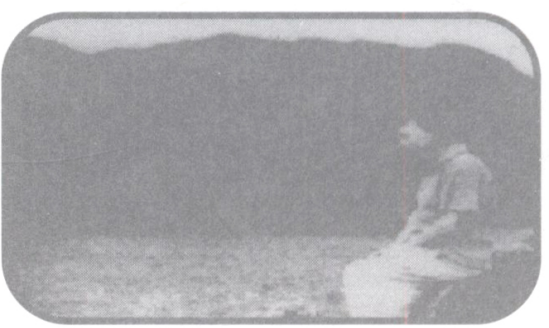

Now in Paperback!

Pursued by Furies

A Life of Malcolm Lowry

\section{Gordon Bowker}

"In this ruthlessly probing biography. Bowker skillfully navigates the maze of Lowry's messy life.

-PUBLISHERS WEEKLY

"Bowker draws a convincing and chilling portrait." -THE NEW YORKER

April $1997 / 696$ pp. with b\&w photos ISBN 0-312-16356-8 \$19.95 pb. 